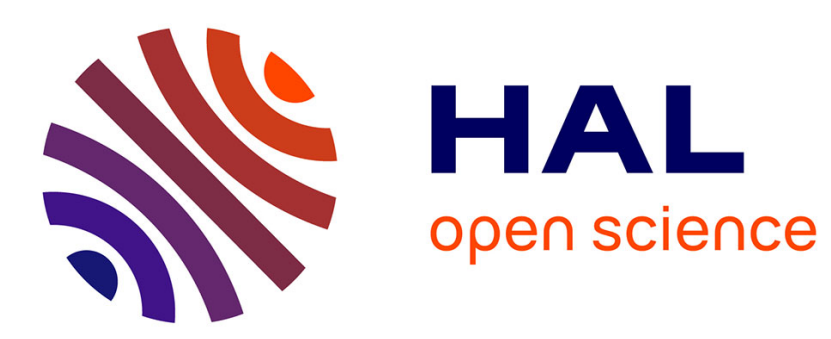

\title{
Abnormal loan growth, credit information sharing and systemic risk in Asian banks
}

Wahyoe Soedarmono, Djauhari Sitorus, Amine Tarazi

\section{To cite this version:}

Wahyoe Soedarmono, Djauhari Sitorus, Amine Tarazi. Abnormal loan growth, credit information sharing and systemic risk in Asian banks. 2017. hal-01558249

\section{HAL Id: hal-01558249 \\ https://hal-unilim.archives-ouvertes.fr/hal-01558249}

Preprint submitted on 10 Jul 2017

HAL is a multi-disciplinary open access archive for the deposit and dissemination of scientific research documents, whether they are published or not. The documents may come from teaching and research institutions in France or abroad, or from public or private research centers.
L'archive ouverte pluridisciplinaire HAL, est destinée au dépôt et à la diffusion de documents scientifiques de niveau recherche, publiés ou non, émanant des établissements d'enseignement et de recherche français ou étrangers, des laboratoires publics ou privés. 


\title{
Abnormal loan growth, credit information sharing and systemic risk in Asian banks
}

\author{
Wahyoe Soedarmono \\ Sampoerna University, Jakarta, Indonesia \\ Djauhari Sitorus \\ World Bank Group, Washington DC, USA \\ Amine Tarazi ${ }^{1}$ \\ Université de Limoges, LAPE, France
}

\begin{abstract}
This paper investigates the interplay of abnormal loan growth, credit reporting system and systemic risk in banking. Based on a sample of publicly traded banks in Asia from 1998 to 2012, higher abnormal loan growth leads to higher systemic risk one year ahead. A closer investigation further suggests that better credit information coverage and private credit bureaus can stem the buildup of bank systemic risk one year ahead due to higher abnormal loan growth. Eventually, this paper offers some supports to strengthen macro-prudential regulation to limit abnormal loan growth. This paper also advocates the importance of strengthening credit information coverage and the role of private credit bureaus in Asian countries to mitigate the negative impact of abnormal loan growth on bank systemic stability.
\end{abstract}

JEL Classification: G21, G28

Keywords: Abnormal loan growth, systemic risk, credit reporting system, Asian banks

\footnotetext{
${ }^{1}$ Corresponding author.

Email: wahyoe.soedarmono@sampoernauniversity.ac.id (W. Soedarmono), dsitorus@worldbank.org (D. Sitorus), amine.tarazi@unilim.fr (A. Tarazi). The views expressed in this paper are the authors' and do not necessarily reflect those of the World Bank, its Executive Directors, or the countries they represent.
} 


\title{
Abnormal loan growth, credit information sharing and systemic risk in Asian banks
}

\begin{abstract}
This paper investigates the interplay of abnormal loan growth, credit reporting system and systemic risk in banking. Based on a sample of publicly traded banks in Asia from 1998 to 2012, higher abnormal loan growth leads to higher systemic risk one year ahead. A closer investigation further suggests that better credit information coverage and private credit bureaus can stem the buildup of bank systemic risk one year ahead due to higher abnormal loan growth. Eventually, this paper offers some support to strengthen macroprudential regulation to limit abnormal loan growth. This paper also advocates the importance of strengthening credit information coverage and the role of private credit bureaus in Asian countries to mitigate the negative impact of abnormal loan growth on bank systemic stability.
\end{abstract}

JEL Classification: G21, G28

Keywords: Abnormal loan growth, systemic risk, credit reporting system, Asian banks 


\section{Introduction}

The 2008 credit crisis due to the rapid growth of the subprime mortgage lending has raised concerns for policy makers, as higher financial intermediation might exacerbate financial instability. A large number of studies have documented that excessive loan growth is indeed detrimental for bank stability, which may end up in financial crisis (e.g. Demyanyk and Van Hermet, 2011; Dell' Ariccia et al., 2008; Gorton, 2009; Foos et al., 2010; Festić et al., 2011). Such evidence also sheds light on the fact that bank lending and thus credit risk are procyclical through the business cycle. Phrased differently, banks tend to underestimate credit risk by loosening credit standards during economic booms, but overestimate credit risk during economic downturns (Berger and Udell, 2004).

Accordingly, ensuring prudent lending decisions has become a major policy focus related to bank capital regulation. In the Basel III accord particularly, such bank capital regulation has been refined not only to absorb bank risk exposures, but also to stem the buildup of systemic risk driven by business cycle fluctuations (Arnold et al., 2013). For instance, banks are required to generate counter-cyclical capital buffer during economic booms in order to dampen excessive loan growth. Therefore, it is expected that banks already have sufficient "reserves" to boost lending activities and help economic recovery during economic downturns.

Despite the importance of regulating imprudent bank lending decisions to mitigate the buildup of bank systemic risk, prior literature has not explicitly revealed how loan growth affects systemic risk in banking. Only the link between loan growth and bank-specific riskiness is empirically analyzed, notably in the context of developed countries (e.g. Sinkey and Greenwalt, 1991; Salas and Saurina, 2002; Hess et al., 2009; Foos et al., 2010). Yet, although several studies have examined how bank loan growth affects macroeconomic development and stability in developing countries and transition economies (e.g. Cotarelli et al., 2005; Kraft and Jankov, 2005; Festić et al., 2011), the issue of bank systemic risk also remains unexplored.

This paper aims to extend previous work on the link between abnormal loan growth and bank riskiness in two directions. First, we examine the impact of abnormal loan growth on bank systemic risk instead of bank-level riskiness as in the aforementioned studies. Second, we augment the analysis by assessing whether the impact of abnormal loan growth on bank systemic risk is conditional on the degree of credit information sharing, because greater asymmetric information on the credit market may result in financial instability (e.g. Mishkin, 1991; Sau, 2003). From the latter contribution, this paper is the first to build an 
empirical link between the "growth-risk nexus in bank lending" literature and the "information sharing-stability" literature.

In this paper, Asian countries are taken into close consideration, as the banking sector plays a prominent role in providing financial sources for private sector businesses. In the meantime, only few papers have studied the issue of loan growth in Asian banking (e.g. Craig et al., 2006; Angklomkliew et al., 2009; Packer and Zhu, 2012). Considering Asian countries to study the issues of loan growth, credit information sharing and systemic risk is also quite relevant in several respects. For instance, Hong Kong and South Korea have experienced rapid credit growth that outstripped bank ability to cope with credit risk (Asia Focus, 2011). During the 2000s decade, credit card defaults and personal bankruptcies were prevalent in these two countries. Moreover, Indonesia, Malaysia, Thailand, the Philippines, Hong Kong and South Korea were also the countries affected by the 1997 Asian crisis due to excessive bank lending, particularly in property and real estate sectors (Sachs and Woo, 2000; Soedarmono et al., 2013). Such evidence suggests the need for Asian banks to strengthen credit risk management. Eventually, the quality of credit reporting system in strengthening bank credit risk management through better information sharing on the creditworthiness of borrowers, should be of concern for policy makers at least in the Asian context.

From a dynamic panel data methodology, we find that higher abnormal loan growth is associated with an increase in bank systemic risk one year ahead. A closer investigation further reveals that better credit information coverage and private credit bureaus - but not public credit registries - can mitigate the buildup of bank systemic risk driven by higher abnormal loan growth. These findings emphasize the importance of the quality of credit information coverage and private credit bureaus, in order to mitigate the adverse impact of abnormal loan growth on systemic stability.

The rest of this paper is structured as follows. Section 2 presents related literature on the issues of bank loan growth, risk and credit information sharing. Section 3 describes data sources, variables and methodology used in this paper. Section 4 discusses empirical findings and provides several robustness checks. Section 5 concludes the paper. 


\section{Related literature review}

During economic booms, it is perceived that banks tend to underestimate credit risk and boost lending activities (Borio et al., 2001; Berger and Udell, 2004). Such bank behavior is referred to as the procyclicality of bank lending and risk management, as banks are likely to overestimate credit risk and reduce lending during economic downturns, which may in turn precipitate recessions (e.g. Bikker and Metzemakers, 2005; Bouvatier and Lepetit, 2008 \& 2012).

Because bank lending and credit risk management tend to be procyclical over the business cycle, it may imply that excessive bank loan growth during economic booms may exacerbate the buildup of bank riskiness. Salas and Saurina (2002) use a large set of Spanish commercial banks during the 1985-1997 period, and find that the loan growth of banks has impacted bank stability. Their results highlight that higher loan growth is associated with higher loan losses three (or four) years ahead. Laeven and Majnoni (2003) also point out that banks tend to delay provisioning for non-performing loans until it is too late - when recession already set in.

From a sample of Australasian banks over the 1980-2005 period, Hess et al. (2009) examine the determinants of loan losses and show that higher loan growth is associated with higher loan losses two to four years ahead. In parallel, Foos et al. (2010) examine the link between abnormal loan growth and risk from a sample of commercial banks in 16 OECD countries during the 1997-2007 period. In their study, higher abnormal loan growth is associated with higher loan loss provisions during the subsequent three years, lower interest income, lower risk-adjusted interest income, and lower capital ratios. Eventually, Festić et al. (2011) assess the impact of rapid credit growth on bank performance and non-performing loans in Central and Eastern Europe. Their results support the notion that rapid credit growth deteriorates bank performance and exacerbates non-performing loans.

In spite of a growing literature on the growth-risk nexus in bank lending, only few papers embrace the issues of loan growth in Asian banks (e.g. Craig et al., 2006; Angklomkliew e al., 2009; Parker and Zhu, 2012). Craig et al. (2006) examine the determinants of loan loss provisions from a sample of 242 commercial banks in Asian countries. Their results are consistent with the notion that bank credit risk management through loan loss provisions is procyclical, because higher loan growth, real GDP, asset prices and earnings are associated with a decline in loan loss provisions. Angklomkliew et al. (2009) find that higher loan growth leads to lower loan loss provisions during instable periods, but this relationship disappears during stable periods. Yet, Parker and Zhu (2012) 
assess the determinants of loan loss provisions using a sample of 240 banks in 12 Asian countries. For the Asia-Pacific region in particular, they document that the loan loss provisioning practices of Japanese and Southeast Asian banks are procyclical over the business cycle, because higher loan growth and higher real GDP growth lead to a decline in loan loss provisions.

Notwithstanding the importance of overcoming excessive bank loan growth, another strand of literature highlights that bank risk-taking behavior can also be explained by the quality of credit information sharing. The "information sharing-stability" literature suggests that better credit information sharing allows banks to mitigate borrower moral hazard, and to prevent adverse selection due information asymmetry on the credit market (Padilla and Pagano, 2000; Beck et al., 2013). In parallel, several studies also emphasize that better credit reporting systems contribute to boost bank lending activities and economic growth, as well as bank international expansion (e.g. Pagano and Jappelli, 1993; Jappelli and Pagano, 2002; Houston et al.; 2010; Tsai et al., 2011; Love and Mylenko, 2003; Brown et al., 2009; Beck et al., 2013). Given that credit information sharing affects bank stability and financial intermediation, the interplay of bank loan growth and systemic risk may be conditional on the quality of credit information sharing.

Turning to the empirical literature on bank systemic risk, De Nicolo and Kwast (2002) are the first to develop a measure of systemic risk based on the correlation of bank stock returns. They show that the correlation of bank stock returns can reveal financial crisis episodes. In this case, higher correlation of bank stock return indicates financial crisis episodes. Meanwhile, Bautista et al. (2008) consider the correlation of residuals from a single-index market model as a proxy of bank systemic risk. Patro et al. (2013) subsequently compare several measures of bank systemic risk using the correlation approach based on stock market data. Higher bank contagion is largely driven by higher correlation in bank idiosyncratic risk. Finally, Anginer et al. (2014) use the correlation of bank distance-todefault as a measure of bank systemic risk in order to examine the impact of bank competition.

Concomitantly, a large number of studies also use another measure of bank systemic risk based the conditional value-at-risk $(\triangle \mathrm{CoVaR})$ approach (e.g. Acharya et al., 2010; Brownless and Engle, 2011; Adrian and Brunnermeier, 2011). However, measuring bank systemic risk using the correlation approach has advantages over other measures including $\Delta \mathrm{CoVaR}$. This is because the correlation of bank-specific risk can avoid volatility bias that may underestimate bank systemic risk, particularly in good times (Anginer et al., 2014; 
Pukhtuanthong and Roll, 2009; Bekaert and Wang, 2009). Billio et al. (2012) assert that during economic booms, financial innovation emerges and the risk codependence of banks also increases. Meanwhile, substantial bank losses may have not yet materialized in this phase. Using the $\Delta \mathrm{CoVaR}$ approach to account for bank losses in good times results in low levels of $\Delta \mathrm{CoVaR}$ and hence, the high risk codependence among financial institutions that reflects the systemic risk of banks cannot be accurately determined (Anginer et al., 2014).

In this present paper, we use the time-varying correlation of bank-specific risk to account for bank systemic risk. Based on a single-index market model, the time-varying correlation of bank-specific risk is computed using the exponentially-weighted moving average pairwise correlation of idiosyncratic risk among banks following De Nicolo and Kwast (2002), Bautista et al. (2008), and Patro et al. (2013). As a robustness check, we also use the time-varying correlation of bank stock return as an alternative proxy of bank systemic risk. Given that this paper aims to assess the implication of bank loan growth on systemic risk, considering the correlation approach based on either bank idiosyncratic risk or bank stock return can consistently reflect a dimension of bank-specific risk driven by bank lending behavior. In the case of Asian banks, Agusman et al. (2008) have documented that bank credit risk is indeed strongly associated with bank idiosyncratic risk and total risk.

\section{Data, variables and methodology}

\subsection{Data}

Only publicly traded commercial banks (i.e. listed on a stock exchange) are considered in this paper, because bank systemic risk is measured from either the time-varying correlation of bank stock returns, or the time-varying correlation of bank idiosyncratic risk derived from a single-index market model. From Bankscope Fitch IBCA, an unbalanced panel data of balance-sheet and income statement data from 161 listed banks over the 19982012 period is obtained from nine Asian countries. These include China (17), Japan (78), Hong Kong (4), South Korea (3), Indonesia (31), Malaysia (3), Philippines (12), Singapore (3), and Thailand $(10)^{2}$. In the next turn, we retrieve weekly market index values and weekly stock prices of such banks from Thomson-Reuters Datastream International.

The Asian countries considered in this paper are identical to those in Fu et al. (2014) who assess the issue of bank stability in the Asia-Pacific region. However, unlike in Fu et al. (2014), we exclude South Asian countries (India, Pakistan and Sri Lanka), Australia, and

\footnotetext{
${ }^{2}$ The number in parentheses represents the number of banks for each country.
} 
Taiwan for the following reasons. The Indian banking industry is still dominated by the public sector and hence, a non-optimizing behavior of Indian banks is prevalent. Specifically, Soedarmono et al. (2013) document that the Lerner index of the Indian banking industry is negative for the whole period from 1994 to 2009. Therefore, India may exhibit different patterns of bank market structure compared to other Asian countries. Pakistan and Sri Lanka are also excluded, because their stock markets are still relatively underdeveloped compared to other Asian countries (Soedarmono and Tarazi, 2013). Moreover, we also exclude Australia, given that the Australian banking industry is considered as one of the safest banking industry which is neither affected by the 1997 Asian crisis, nor the 2008 global financial crisis (Haq et al., 2013). Finally, Taiwanese banks are also excluded from the sample, because the Doing Business database does not cover data related to credit reporting system in Taiwan.

To assess information sharing activities, we consider several proxies of the quality of the credit reporting system at the country level. This dataset is collected from the Doing Business database developed by the World Bank. We consider Doing Business 2004-2013 to obtain data on the country's credit reporting system in January of 2003 to 2012. However, such information reflects the situation at the end of each year from 2002 to 2012. Following Tsai et al. (2011), because data on the credit reporting system before 2002 is not available, the data in 2002 is used for the earlier time period (1998-2001).

We further incorporate macroeconomic indicators to control for country-specific factors that can influence the degree of bank systemic risk. These include the logarithm of real gross domestic product per capita $(L G D P C)$ and Economic Freedom index (ECOFREE) to control for the degree of economic development and institutional quality, respectively. LGDPC and ECOFREE are retrieved from the Global Financial Development database and Heritage Foundation, respectively.

\subsection{Bank systemic risk}

Building on De Nicolo and Kwast (2002), Bautista et al. (2008) and Patro et al. (2013), we use two measures of bank systemic risk. These include the time-varying correlation of bank idiosyncratic risk (SRISK) and the time-varying correlation of bank stock return $(R C O R R)$.

The time-varying correlation of bank idiosyncratic risk is constructed in three stages. In the first stage, we construct a standard market model as follows:

$$
R_{i, t}=\beta R_{M, t}+\varepsilon_{i, t}
$$


From Eq. (1), $R_{i, t}$ is bank $i$ 's stock return at week $t$, while $R_{M, t}$ stands for weekly stock market returns. We calculate bank stock returns and market returns as follows:

$$
R_{i, t}=\log \left(\frac{p_{t}}{p_{t-1}}\right) \quad R_{M, t}=\log \left(\frac{m_{t}}{m_{t-1}}\right)
$$

In Eq. (2), $p$ and $m$ are defined as weekly bank stock prices and market indexes, respectively.

In the second stage, we estimate Eq. (1) using the OLS (ordinary least squares) regression. In order to obtain the market model that varies from week to week, we estimate Eq. (1) on the basis of a 52 rolling window from $t-51$ up to $t$. In the third stage, we obtain the weekly residuals of Eq. (1), in order to compute an exponentially-weighted moving average correlation between the residuals of bank $i\left(\varepsilon_{i, t}\right)$ and those of bank $j\left(\varepsilon_{j, t}\right)$ in the same country, calculated from $t-51$ up to $t$ based on the following formula:

$$
\rho_{i, j, t}=\frac{\sum_{s=0}^{k} \lambda^{s} \varepsilon_{i, t-s} \varepsilon_{j, t-s}}{\left[\left(\sum_{s=0}^{k} \lambda^{s} \varepsilon_{i, t-s}^{2}\right)\left(\sum_{s=0}^{k} \lambda^{s} \varepsilon_{j, t-s}^{2}\right)\right]^{\frac{1}{2}}}
$$

In Eq. (3), the number of weeks $(k)$ is set to be equal to 51. According to Engle (2002), Eq. (3) denotes the exponential smoother for the correlation matrix. Engle (2002) further emphasize that RiskMetrics also takes into account declining weights reflected in a parameter $\lambda$ that affects the exponential smoother. However, given that no specific rule has been applied to determine $\lambda$, we follow RiskMetrics as in Engle (2002) to set $\lambda$ to 0.94 . Accordingly, $\rho$ is the average weekly correlation between the specific risk of bank $i$ with the specific risk of other banks $j$ in the same country.

Since this study analyzes the impact of bank loan growth on systemic risk based on annual balance-sheet and income statement data, we annualize $\rho$ to obtain the degree of yearly bank systemic risk (SRISK). Higher SRISK reflects higher bank systemic risk. Moreover, the time-varying correlation of bank stock returns $(R C O R R)$ as an alternative proxy of bank systemic risk is also constructed using an exponentially weighted moving average correlation using Eq. (3). In this regard, we use the bank stock return variable instead of the residuals of a single-index market model. Similar to SRISK, higher RCORR is associated with higher bank systemic risk.

\subsection{Abnormal loan growth}


As this paper focuses on the implication on systemic risk of higher abnormal loan growth in banking, we need proxies of abnormal loan growth of banks. Following Foos et al. (2010), abnormal loan growth $(A L G)$ is measured as follows:

$$
A L G_{i, t}=L G_{i, t}-A g L G_{j, t}
$$

In Eq. (4), $A g L G$ denotes the aggregate loan growth measured by the annual growth of total loans in the banking system for each country. $L G$ denotes loan growth at the bank level measured by either DLOAN or LOANG. DLOAN is defined as the actual change in the ratio of total loans $(L)$ to total assets (TA) following Bouvatier and Lepetit (2008), while LOANG is simply the annual growth rate of total loans for each bank. Specifically, DLOAN and LOANG are calculated as follows.

$$
\begin{aligned}
& \operatorname{DLOAN}_{i, t}=\left(L_{i, t}-L_{i, t-1}\right) / 0.5\left(T A_{i, t}+T A_{i, t-1}\right) \\
& \operatorname{LOANG}_{i, t}=\left(L_{i, t}-L_{i, t-1}\right) / L_{i, t-1}
\end{aligned}
$$

For simplicity, we denote abnormal loan growth using $A D L O A N$ if $L G$ and $A g L G$ in Eq. (4) are measured by DLOAN as in Eq. (5). On the other hand, $A L O A N G$ is used to represent abnormal loan growth if $L G$ and $A g L G$ in Eq. (4) is measured by $L O A N G$.

\subsection{Credit reporting system}

To measure credit information sharing that alleviates information asymmetry on the credit market, we use several proxies of the quality of credit reporting system. These proxies include the depth of credit information coverage (CRINDEX), private credit bureau coverage $(P R I V B U R)$ and public credit registry coverage (PUBREG). CRINDEX ranges from 0 to 6 and measures the degree of credit information available in a country regardless of the ownership types of credit bureaus. In general, higher CRINDEX means higher information sharing activities and hence, more credit information from credit bureaus is available to support bank lending decisions. PRIVBUR and PUBREG represent the proportion of individuals and firms whose credit information are registered in private credit bureaus, and public credit registries, respectively ${ }^{3}$. Higher PRIVBUR and PUBREG are both associated with better credit information sharing.

\subsection{Control variables}

\footnotetext{
${ }^{3}$ See the World Bank's Doing Business Database for the details.
} 
In this study, we incorporate several control variables that may affect the degree of bank systemic risk. We include the ratio of total equity to total assets (EQTA), because it is widely perceived that higher bank capitalization strengthens stability. Hence, higher bank capitalization is expected to overcome bank risk and the buildup of systemic risk (e.g. Arnold et al., 2013; Lee and Hsieh, 2013). Bank liquidity is also an important dimension of stability. As such, the ratio of total liquid assets to total deposits and short-term funds (LIQ) is considered as one of the control variables in this study. In addition to that, we incorporate bank credit risk measured by the ratio of loan loss provisions to total assets $(L L P)$. As bank credit risk increases, the buildup of systemic risk also tends to increase. Prior literature also highlights the role of "too-big-to-fail" effects in exacerbating bank risk. Therefore, the logarithm of bank total assets (SIZE) is also included to control for the presence of the "toobig-to-fail" issues in banking (Beck and Laeven, 2006). Finally, the charter value hypothesis and the competition-stability hypothesis highlight that bank systemic risk can also be explained by bank market power (Anginer et al., 2014). In this regard, we incorporate the Tobin's $Q$ ratio (TOBIN) to account for bank market power. Following Keeley (1990) and Haq and Heaney (2012), TOBIN is defined as follows:

$$
\operatorname{TOBIN}_{i, t}=\left(M V E_{i, t}+B V L_{i, t}\right) / T A_{i, t}
$$

$M V E$ denotes the market value of equity, while $B V L$ and $T A$ represent the book value of liabilities and total assets, respectively.

Aside from bank-specific control variables, controlling for country-specific factors is also important to take into account different macroeconomic and institutional characteristics from one country to another. We incorporate two country-specific control variables. These include the degree of institutional development proxied by the degree of economic freedom $(E C O)$, as well as the degree of economic development measured by the logarithm of real GDP per capita $(L G D P C)$.

\subsection{Methodology}

In terms of methodology, we proceed in several stages. In the first stage, we construct two proxies of bank systemic risk (SRISK and RCORR). In the second stage, we examine the link between abnormal loan growth and systemic risk over the 1998-2012 period. For this purpose, we construct the following models as a baseline regression in which $i$ and $j$ represent bank and country indexes, respectively. 


$$
\begin{aligned}
\operatorname{SRISK}_{i, t}= & \beta_{0} \operatorname{SRISK}_{i, t-1}+\beta_{1} \operatorname{ALG}_{i, t-1}+\beta_{2} A L G_{i, t-2}+ \\
& +\beta_{3} \operatorname{EQTA}_{i, t}+\beta_{4} L_{i, t}+\beta_{5} L L P_{i, t}+\beta_{6} \operatorname{SIZE}_{i, t} \\
& +\beta_{7} \operatorname{TOBIN}_{i, t}+\beta_{8} E_{j, t}+\beta_{9} L G D P C_{j, t} \\
\operatorname{RCORR}_{i, t}= & \beta_{0} \operatorname{RCORR}_{i, t-1}+\beta_{1} A L G_{i, t-1}+\beta_{2} A L G_{i, t-2}+ \\
& +\beta_{3} \operatorname{EQTA}_{i, t}+\beta_{4} L I Q_{i, t}+\beta_{5} L L P_{i, t}+\beta_{6} \operatorname{SIZE}_{i, t} \\
& +\beta_{7} \operatorname{TOBIN}_{i, t}+\beta_{8} \operatorname{ECO}_{j, t}+\beta_{9} L G D P C_{j, t}
\end{aligned}
$$

Eq. (7a) and Eq. (7b) represent the systemic risk equations where SRISK and RCORR are used as a proxy of bank systemic risk, respectively. Unlike Foos et al. (2010) who examine the impact of abnormal loan growth on bank risk one year to two years ahead, we only consider the impact of abnormal loan growth on bank systemic risk one year to two years ahead as in Eq. (7a) and Eq. (7b). This consideration is made because Foos et al. (2010) have a large number of banks and observations compared to this present study ${ }^{4} . A L G$ used in Eq. (7a) and (7b) comprises two measures of abnormal loan growth, either ADLOAN or ALOANG. In the third stage, we augment Eq. (7a) and Eq. (7b) by incorporating the interaction term between abnormal loan growth and credit reporting system.

Credit reporting system is represented by CRINDEX, PRIVBUR, or PUBREG. Nevertheless, we do not define regression models incorporating these interaction terms at this stage, because such interaction terms depend on the empirical results obtained from Eq. (7a) and Eq. (7b). In other words, it is still unclear at this stage whether credit reporting system variables should be interacted with $A L G_{t-1}, A L G_{t-2}$, or both.

To estimate Eq. (7a) and Eq. (7b), we use the dynamic panel data methodology developed by Arellano and Bover (1995) and Blundell and Bond (1998). Indeed, several studies point out that the current bank performance might be affected by its past values (e.g. Naceur and Kandil, 2009; Naceur and Omran, 2011). In this sense, current bank systemic risk might also be dependent on its past values. We follow Blundell and Bond (1998) to use the two-step generalized methods of moments (GMM) or the system GMM in estimating our dynamic panel data models. Baltagi (2005) shows that the system GMM produces more efficient output than the one-step GMM.

\footnotetext{
${ }^{4}$ As a robustness check, we also examine the impact of abnormal loan growth on systemic risk one year to four years ahead. However, the empirical results are not altered. These results are not presented in this paper, but are available upon request.
} 
In estimating the system GMM, we also take into account a finite sample correction following Windmeijer (2005) to provide robust estimates. We further specify orthogonal deviation transformations of instruments to control for bank-level fixed effects as in Foos et al. (2010). Time-specific dummy variables are also incorporated in our panel data estimation to control for time-fixed effects associated business cycle fluctuations. Overall, the system GMM estimation is valid, as long as the AR(2) test and Hansen-J test are not statistically significant. This indicates that there is no second-order autocorrelation among residuals of the first-differenced equation, and that the identifying restrictions in dynamic panel data models are valid, respectively.

\section{Results}

\subsection{Descriptive statistics and correlation structure}

In Table 1, we present the descriptive statistics of all variables used in this study. Moreover, Table 2 shows the correlation structure of all variables. No notable correlation can be detected among bank-specific variables used in this study, although country-specific variables exhibit high correlation. In this regard, we conduct the variance inflation test (VIF) to check whether or not multicollinearity is an issue.. The VIF coefficients of all regressions show that the VIF is less than 5 and hence, multicollinearity issues are less of a concern ${ }^{5}$.

[Insert Table 1 and Table 2]

\subsection{Empirical results}

Table 3 documents the impact of abnormal loan growth on systemic risk in banking. From the system GMM, it is shown that higher abnormal loan growth based on either $A D L O A N$ or $A L O A N G$ is associated with higher systemic risk one year ahead regardless of whether SRISK and RCORR is used as a proxy of bank systemic risk. These results are consistent with previous studies highlighting that higher abnormal loan growth is detrimental to bank stability (e.g. Foos et al., 2010; Festić et al., 2011; Hess et al., 2009). However, we find that the impact of bank abnormal loan growth on systemic risk two years ahead is not statistically significant. Overall, the empirical results obtained from the system GMM estimation shown in Table 3 are valid, because AR(2) and Hansen-J tests are not significant, at least at the 5 percent level.

\footnotetext{
${ }^{5}$ The results of the VIF test are not presented in this paper, but are available upon request.
} 
[Insert Table 3 here]

In the next turn, we examine whether the impact of abnormal loan growth on systemic risk one year ahead is dependent on the quality of credit information sharing. Here, we only focus on the joint impact of abnormal loan growth (ADLOAN or ALOANG) and credit information sharing (CRINDEX, PRIVBUR or PUBREG) on bank systemic risk one year ahead, given that only the one-period-lagged value of abnormal loan growth is significant. Table 4 presents the empirical results obtained from the system GMM estimation for this purpose, particularly when SRISK is used as a proxy of bank systemic risk. Meanwhile, Table 5 presents the empirical results when RCORR is used as a proxy of bank systemic risk.

\section{[Insert Table 4 and Table 5]}

Table 4 and Table 5 show that higher abnormal loan growth measured by either $A D L O A N$ or $A L O A N G$ still exhibits a positive and significant impact on bank systemic risk (SRISK or RCORR) one year ahead. With regards to $A L G(-1)$ x $C R I N D E X(-1)$, higher oneperiod-lagged value of CRINDEX is found to have a moderating effect on the impact of abnormal loan growth on systemic risk one year ahead. However, the positive impact of abnormal loan growth on systemic risk one year ahead remains, but with a lower magnitude for countries with higher credit information index. This result holds when ADLOAN is used as a proxy of abnormal loan growth. If $A L O A N G$ is used as a proxy of abnormal loan growth, the sign of $A L G(-1)$ x $C R I N D E X(-1)$ remains negative, albeit not significant. Both models using $A B D L O A N$ and $A B L O A N G$ as the abnormal loan growth measure are also valid, because the AR(2) test and Hansen-J test are not significant, at least at the 5 percent level.

Moreover, in order to examine the type of credit reporting system that matters in affecting the buildup of bank systemic risk due to abnormal loan growth, we consider the role of private credit bureaus (PRIVBUR) and public credit registries (PUBREG). From Table 4 and Table 5, it is shown that the positive sign on $A L G(-1)$ is outweighed by the negative coefficient of $A L G(-1)$ x $P R I V B U R(-1)$. In other words, the absolute value of the coefficient of $A L G(-1)$ x PRIVBUR(-1) is higher than the absolute value of the coefficient of $A L G(-1)$. This indicates that higher abnormal loan growth leads to an increase in systemic risk, particularly if the value taken by PRIVBUR is very low, but to a decline in the systemic risk of banks when the quality of private credit bureaus (PRIVBUR) improves. These results are 
robust regardless of the use of $A D L O A N$ or $A L O A N G$ as a proxy of abnormal loan growth. All dynamic panel data models are also valid, because the AR(2) test and Hansen-J test are not rejected at least at the 5 percent level.

Unlike the influence of private credit bureaus that may reverse the impact of the oneperiod-lagged value of abnormal loan growth on systemic risk, the role of public credit registries in the growth-systemic risk nexus in bank lending remains unclear. Table 4 and Table 5 show that no coefficients related to $A L G(-1)$ x $P U B R E G(-1)$ are statistically significant. Finally, the empirical results are also valid because the AR(2) test and Hansen-J test are not significant.

With regards to the influence of bank-specific control variables, only the bank capital ratio (EQTA) has no significant impact on bank systemic risk as shown in Table 4 and Table 5. Meanwhile, higher bank liquidity $(L I Q)$ is associated with lower bank systemic risk measured by either SRISK or RCORR. Concomitantly, as banks hold more LLP, their systemic risk declines considerably. This is presumably because higher LLP is used by banks to cover the buildup of credit risk which in turn reduces the correlation of bank-specific risk. Moreover, from Table 3 to 5, it is also shown that the larger the size of banks (SIZE), the higher the degree of bank systemic risk. This result is consistent with the presence of "toobig-to-fail" effects in which larger bank size is associated with greater bank moral hazard (e.g. Galloway et al., 1997; Beck and Laeven, 2006). Concerning the impact of TOBIN on bank systemic risk, we document robust evidence that higher TOBIN results in lower bank systemic risk. This result follows the "charter value hypothesis" in which bank market power becomes a self-disciplining factor of risk taking (e.g. Keeley, 1990; Ariss, 2010). In this context, higher bank market power reduces bank incentives to undertake excessive risk taking and hence, bank systemic risk also tends to decline. Finally, the degree of economic freedom and economic development as country-specific control variables have no clear impact on bank systemic risk from Table 3 to Table 5 .

\subsection{Robustness checks}

To this end, although the empirical findings are robust to different proxies of abnormal loan growth and systemic risk, additional robustness checks are also undertaken. The results of robustness checks are not presented in this paper, but are available upon request.

First, because the impact of country-specific control variables (ECOFREE and $L G D P C$ ) on systemic risk are not consistent as shown from Table 3 to Table 5, we exclude 
country-specific variables. This consideration is also made, because all of country-specific variables exhibit strong correlation. However, the impact of abnormal loan growth on systemic risk one year ahead, as well as the role of private credit bureaus in coping with an increase in systemic risk due to higher one-period-lagged value of abnormal loan growth, remains unaltered.

Second, we consider the impact of abnormal loan growth on systemic risk one year to four years ahead following Foos et al. (2010). The empirical results are not altered, but the number of observations declines considerably.

Finally, in order to eliminate the impact of the 1997/1998 Asian crisis that might affect banking stability in Asia, we reestimate regression models that produce Table 3 to Table 5, but only for the 2001-2012 period. The number of observations declines, but the impact of abnormal loan growth and credit reporting system on systemic risk one year to two years ahead remains unaltered.

\section{Conclusion}

This paper is the first to analyze how abnormal loan growth can affect bank systemic risk in emerging markets. From a sample of publicly traded commercial banks in the AsiaPacific region, the empirical results show that the differences in bank systemic risk can be explained by the one-period-lagged value of abnormal loan growth. Differently phrased, higher abnormal loan growth increases bank systemic risk one year ahead. However, these results are conditional on the quality of credit information sharing at the country level. In countries with a higher credit information index and better private credit bureaus, the positive impact of the one-year-lagged value of abnormal loan growth on systemic risk is reversed. Hence, the adverse impact of abnormal loan growth on bank systemic stability only occurs in countries with lower quality of credit information sharing, especially if private credit bureaus have lower quality. Overall, these results are robust to different measures of abnormal loan growth and systemic risk.

Eventually, this paper highlights some policy implications at least in the Asian context. While overcoming abnormal loan growth is necessary to deal with the buildup of bank systemic risk, each country has different characteristics in terms of their credit market imperfections. In this regard, bank regulators can consider the role of credit information sharing in mitigating the adverse impact of abnormal loan growth as a complement of macroprudential regulation. As such, strengthening the quality of private credit bureaus is worth considering. 


\section{References}

Acharya V., Pedersen L.H., Philippon T., Richardson M.P. 2010. Measuring systemic risk. AFA 2011 Denver Meetings Paper

Adrian T. and Brunnermeier M. K. 2011. CoVaR. NBER working papers No. 17454

Agusman, A., Monroe, G.S., Gasbarro, D., Zumwalt, K., 2008. Accounting and capital market measures of risk: Evidence from Asian banks during 1998-2003. Journal of Banking and Finance 32(4), 480-488

Anginer, D., Demirguc-Kunt, A., Zhu, M., 2014. How does competition affect bank systemic risk? Journal of Financial Intermediation 23(1), 1-26

Angklomkliew, S., J. George, F. Packer, 2009, Issues and developments in loan loss provisioning: The case of Asia, BIS Quarterly Review, December

Arellano, M., Bover, D., 1995. Another look at the instrumental variable estimation of errorcomponent models. Journal of Econometrics 68, 29-51

Arnold B., Borio C., Ellis L., Moshirian F., 2013. Systemic risk, macroprudential policy frameworks, monitoring financial systems and the evolution of capital adequacy. Journal of Banking and Finance 36 (12), 3125-3132

Asia Focus, 2011. Credit bureaus in Asia. Federal Reserves Banks of San Fransisco, October

Baltagi, B.H., 2005. Econometric analysis of panel data (3rd ed). Chichester: John Wiley \& Sons Ltd

Bautista C., Rous P., and Tarazi A. 2008. The determinants of domestic and cross-border bank contagion in Southeast Asia. Revue Economique 59 (6), 1215-1242

Beck, T., Jonghe, O.D., Schepens, G., 2013. Bank competition and stability: Cross-country heterogeneity. Journal of Financial Intermediation 22, 218-244

Beck, Thorsten, Laeven, Luc, 2006. Resolution of Failed Banks by Deposit Insurers CrossCountry Evidence, World Bank Policy Research Working Paper No. 3920

Bekaert, G., Wang, X., 2009. Globalization and Asset Prices. Working Paper, Columbia University

Berger, A., Udell, G., 2004. The institutional memory hypothesis and the procyclicality of bank lending behavior. Journal of Financial Intermediation 13, 458-495

Bikker, J.A., P. Metzemakers, 2005, Bank provisioning behaviour and procyclicality, Journal of International Financial Markets, Institutions and Money 15, 141-157 
Billio, M., Pelizzon, L., Lo, A., Getmansky, M., 2012. Econometric measures of connectedness and systemic risk in the finance and insurance sectors. J. Financ. Econ. 104, $535-559$

Blundell, R., Bond, S., 1998. Initial conditions and moment restrictions in dynamic panel data models. Journal of Econometrics 87, 115-143

Borio, C., C. Furfine, P. Lowe, 2001, Procyclicality of the financial system and the financial stability: issues and policy options, Bank for International Settlements, Working Paper No.1, pp. $1-57$

Bouvatier, V., Lepetit, L., 2012. Effects of loan loss provisions on growth in bank lending: Some international comparisons. International Economics 132, 91-116

Bouvatier, V., Lepetit, L., 2008, Banks' procyclical behaviour: does provisioning matter? Journal of International Financial Markets, Institutions and Money 18, 513-526

Brown, M., Jappelli, T., Pagano, M., 2009. Information sharing and credit: Firm-level evidence from transition countries. Journal of Financial Intermediation 18, 151- 172

Brownlees C., Engle R. 2011. Volatility, correlation and tails for systemic risk measurement. New York University Working Paper

Cottarelli, C., Dell'Ariccia, G., Vladkova-Hollar, I., 2005. Early birds, late risers, and sleeping beauties: Bank credit growth to the private sector in Central and Eastern Europe and in the Balkans. Journal of Banking and Finance 29, 83-104

Craig, R.S., E.P. Davis, A.G. Pascual, 2006, Sources of procyclicality in East-Asian financial systems, IMF Working Paper

De Nicolo G. \& Kwast M. 2002. Systemic risk and financial consolidation: are they related?. Journal of Banking and Finance 26, 861-880

Dell'Ariccia, G., Igan, D., Laeven, L., 2008. Credit booms and lending standards: Evidence from the subprime mortgage market, IMF Working Paper 08/106

Demyanyk, Y., van Hemert, O., 2011. Understanding the subprime mortgage crisis. Review of Financial Studies 24 (6), 1848-1880

Engle, R., 2002. Dynamic conditional correlation: a simple class of multivariate GARCH. Journal of Business and Economic Statistics 17 (5), 425-446

Festić, M., Kavkler, A., Repina, S., 2011. The macroeconomic sources of systemic risk in the banking sectors of five new EU member states. Journal of Banking and Finance 35, 310-322

Foos, D., Norden, L., Weber, M., 2010. Loan growth and riskiness of banks. Journal of Banking and Finance 34, 2929 - 2940

Gorton, G., 2009. Information, liquidity, and the (ongoing) panic of 2007. American Economic Review 99, 567-572 
Haq, M., Tarazi, A., Avkiran, N, Fonseca, AR., 2013. Market discipline and bank charter value: The case of two safe banking industries. LAPE Working Papers hal-00955135, HAL, Universite de Limoges, France

Haq, M., Heaney, R., 2012. Factors determining European bank risk. Journal of International Financial Markets, Institutions and Money 22, 696-718

Hess, K., Grimes, A., Holmes, M., 2009. Credit losses in Australasian banking. Economic Record 85, 331-343

Houston, J.F., Lin, C., Lin, P., Ma, Y., 2010. Creditor rights, information sharing and bank risk taking. Journal of Financial Economics 96, 485-512

Jappelli, T., Pagano, M., 2002. Information sharing, lending and defaults: Crosscountry evidence. Journal of Banking and Finance 26, 2017-2045

Keeley, M.C., 1990. Deposit insurance, risk, and market power in banking. American Economic Review 80 (5), 1183-1200

Kraft, E., Jankov, L., 2005. Does speed kill? Lending booms and their consequences in Croatia. Journal of Banking and Finance 29, 105-121

Laeven, L., Majnoni, G., 2003. Loan loss provisioning and economic slowdowns: Too much, too late. Journal of Financial Intermediation 12, 178-197

Lee C.C., Hsieh M.F. 2013. The impact of bank capital on profitability and risk in Asian banking. Journal of International Money and Finance 32, 251-281

Love, I., Mylenko, N., 2003. Credit reporting and financing constraints. Working Paper 3142, World Bank Policy Research

Mishkin, F., 1991. Asymmetric information and financial crises: A historical perspective. NBER Working Paper No.3400

Naceur, S.B., Omran, M., 2011. The effects of bank regulations, competition and financial reforms on banks' performance. Emerging Markets Review 12(1), 1-20

Naceur, S.B., Kandil, M., 2009. The impact of capital requirements on banks' cost of intermediation and profitability. Journal of Economics and Business 61, 70-89

Padilla, A.J., Pagano, M., 2000. Sharing default information as a borrower discipline device. European Econonomic Review 44 (10), 1951-1980

Packer, F., Zhu, H., 2012. Loan loss provisioning practices of Asian banks. BIS Working Paper No. 375

Pagano, M., Jappelli, T., 1993. Information sharing in credit markets. Journal of Finance 48, $1693-1718$ 
Patro D., Qi M., and Sun X. 2013. A simple indicator of systemic risk. Journal of Financial Stability 9, 105-116

Pukthuanthong, K., Roll, R., 2009. Global market integration: an alternative measure and its application. Journal of Financial Economics 94 (2), 214-232

Sachs, J., Woo, W.T., 2000. Understanding the Asian financial crisis. In: Sachs, J.D., Schwab, K. (Eds.), The Asian Financial Crisis: Lessons for a Resilient Asia. MIT Press, Cambridge, USA

Salas, V., Saurina, J., 2002. Credit risk in two institutional regimes: Spanish commercial and savings banks. Journal of Financial Services Research 22, 203-224

Sau, L., 2003. Banking, information and instability in Asia. Journal of Post-Keynesian Economics 25(3), 493-513

Sinkey, J., Greenawalt, M., 1991. Loan-loss experience and risk-taking behavior at large commercial banks. Journal of Financial Services Research 5, 43-59

Soedarmono, W., Tarazi, A., 2013. Bank opacity, intermediation cost and globalization. Journal of Asian Economics 29, 91-100

Soedarmono, W., Machrouh, F., Tarazi, A., 2013. Bank competition, crisis and risk taking: Evidence from emerging markets in Asia. Journal of International Financial Markets, Institutions and Money 23, 196-221

Tsai, H., Chang, Y., Hsiao, PH., 2011. What drives foreign expansion of the top 100 multinational banks? The role of the credit reporting system. Journal of Banking and Finance $35,588-605$ 


\section{Appendix}

Table 1. Descriptive statistics

\begin{tabular}{|c|c|c|c|c|c|c|}
\hline Variable & Definition & Obs & Mean & Std. Dev. & Min & Max \\
\hline SRISK & Time-varying correlation of bank idiosyncratic risk & 1979 & 0.234593 & 0.1654178 & -0.232124 & 0.681258 \\
\hline RCORR & Time-varying correlation of bank stock return & 1971 & 0.393667 & 0.2021173 & -0.113587 & 0.866503 \\
\hline$A B L O A N G$ & Abnormal loan growth based on $L O A N G$ & 1502 & 0.047372 & 0.1677793 & -0.84079 & 1.435148 \\
\hline EQTA & Ratio of total equity to total assets & 1823 & 0.068388 & 0.0363215 & 0.00045 & 0.24103 \\
\hline SIZE & Logarithm of bank total assets & 1867 & 16.28897 & 1.80725 & 10.57681 & 21.63956 \\
\hline TOBIN & Tobin's Q ratio & 1646 & 1.015316 & 0.0724614 & 0.867954 & 1.489556 \\
\hline ECOFREE & Economic freedom index & 2595 & 0.654654 & 0.0888693 & 0.51 & 0.9 \\
\hline$L G D P C$ & Logartihm of real GDP per capita & 2254 & 9.03335 & 1.552954 & 6.885752 & 10.52367 \\
\hline CRINDEX & Credit information index & 2595 & 0.047241 & 0.014759 & 0.02 & 0.06 \\
\hline
\end{tabular}


Table 2. Correlation structure

\begin{tabular}{|c|c|c|c|c|c|c|c|c|c|c|c|c|c|c|}
\hline Variables & SRISK & RCORR & $A D L O A N$ & $A L O A N G$ & $E Q T A$ & $L I Q$ & $L L P$ & SIZE & TOBIN & ECOFREE & $L G D P C$ & CRINDEX & PRIVBUR & PUBREG \\
\hline SRISK & 1 & & & & & & & & & & & & & \\
\hline RCORR & 0.81 & 1 & & & & & & & & & & & & \\
\hline$A D L O A N$ & 0.2208 & -0.0172 & 1 & & & & & & & & & & & \\
\hline$A L O A N G$ & 0.0007 & -0.1152 & 0.6893 & 1 & & & & & & & & & & \\
\hline EQTA & -0.3828 & -0.1258 & -0.3122 & -0.0562 & 1 & & & & & & & & & \\
\hline$L I Q$ & -0.4981 & -0.3263 & -0.3999 & -0.0065 & 0.4358 & 1 & & & & & & & & \\
\hline$L L P$ & -0.1843 & -0.0871 & 0.0261 & -0.0256 & 0.0924 & 0.0986 & 1 & & & & & & & \\
\hline SIZE & 0.5956 & 0.6372 & 0.115 & -0.0065 & -0.308 & -0.3588 & -0.0908 & 1 & & & & & & \\
\hline TOBIN & -0.3734 & -0.2276 & -0.2456 & -0.0335 & 0.274 & 0.4148 & 0.095 & -0.1309 & 1 & & & & & \\
\hline ECOFREE & 0.4376 & 0.3933 & 0.286 & -0.0458 & -0.3367 & -0.5426 & -0.1719 & 0.3556 & -0.3313 & 1 & & & & \\
\hline$L G D P C$ & 0.5713 & 0.3026 & 0.5019 & 0.0995 & -0.5739 & -0.728 & -0.2193 & 0.4165 & -0.4628 & 0.8211 & 1 & & & \\
\hline CRINDEX & 0.569 & 0.3199 & 0.5174 & 0.0988 & -0.5787 & -0.7774 & -0.1525 & 0.4035 & -0.4391 & 0.6731 & 0.9057 & 1 & & \\
\hline PRIVBUR & 0.5718 & 0.3773 & 0.3698 & 0.0122 & -0.5155 & -0.7062 & -0.2255 & 0.3812 & -0.4682 & 0.8421 & 0.9205 & 0.8562 & 1 & \\
\hline PUBREG & -0.3725 & -0.3129 & -0.334 & -0.0413 & 0.3163 & 0.4403 & 0.0841 & -0.2158 & 0.4313 & -0.5746 & -0.5611 & -0.4178 & -0.5722 & 1 \\
\hline
\end{tabular}


Table 3. Abnormal loan growth and systemic risk in banking

\begin{tabular}{|c|c|c|c|c|}
\hline \multirow[b]{3}{*}{ Explanatory variables } & \multicolumn{4}{|c|}{ Dependent variables } \\
\hline & SRISK & RCORR & SRISK & RCORR \\
\hline & \multicolumn{2}{|c|}{$A L G=A D L O A N$} & \multicolumn{2}{|c|}{$A L G=A L O A N G$} \\
\hline Dependent var. (-1) & $\begin{array}{l}0.53606^{* * *} \\
(0.073)\end{array}$ & $\begin{array}{l}0.60895 * * * \\
(0.055)\end{array}$ & $\begin{array}{l}0.52617 * * * \\
(0.070)\end{array}$ & $\begin{array}{l}0.59054 * * * \\
(0.057)\end{array}$ \\
\hline$A L G(-1)$ & $\begin{array}{l}0.00097 \\
(0.047)\end{array}$ & $\begin{array}{l}0.09693 * * * \\
(0.038)\end{array}$ & $\begin{array}{l}0.03625 * * * \\
(0.018)\end{array}$ & $\begin{array}{l}0.04712 * * * \\
(0.019)\end{array}$ \\
\hline$A L G(-2)$ & $\begin{array}{l}-0.05613 \\
(0.027)\end{array}$ & $\begin{array}{l}0.01734 \\
(0.029)\end{array}$ & $\begin{array}{l}0.01982 \\
(0.017)\end{array}$ & $\begin{array}{l}0.01373 \\
(0.021)\end{array}$ \\
\hline$E Q T A$ & $\begin{array}{l}-0.00118 \\
(0.002)\end{array}$ & $\begin{array}{l}0.00093 \\
(0.001)\end{array}$ & $\begin{array}{l}-0.00180 \\
(0.002)\end{array}$ & $\begin{array}{l}0.00081 \\
(0.001)\end{array}$ \\
\hline$L I Q$ & $\begin{array}{l}-0.07957 * * \\
(0.039)\end{array}$ & $\begin{array}{l}-0.09169 * * \\
(0.041)\end{array}$ & $\begin{array}{l}-0.08808 * \\
(0.052)\end{array}$ & $\begin{array}{l}-0.12376 * * * \\
(0.047)\end{array}$ \\
\hline$L L P$ & $\begin{array}{l}-0.92668 * \\
(0.534)\end{array}$ & $\begin{array}{l}-0.37571 \\
(0.462)\end{array}$ & $\begin{array}{l}-0.98270 * * \\
(0.496)\end{array}$ & $\begin{array}{l}-0.40934 \\
(0.418)\end{array}$ \\
\hline$S I Z E$ & $\begin{array}{l}0.02299 * * * \\
(0.005)\end{array}$ & $\begin{array}{l}0.03195^{* * * *} \\
(0.005)\end{array}$ & $\begin{array}{l}0.02351 * * * \\
(0.004)\end{array}$ & $\begin{array}{l}0.03313^{* * * *} \\
(0.005)\end{array}$ \\
\hline TOBIN & $\begin{array}{l}-0.13596^{* *} \\
(0.061)\end{array}$ & $\begin{array}{l}-0.11154^{*} \\
(0.060)\end{array}$ & $\begin{array}{l}-0.14124 * * \\
(0.058)\end{array}$ & $\begin{array}{l}-0.10440 \\
(0.065)\end{array}$ \\
\hline ECOFREE & $\begin{array}{l}-0.03581 \\
(0.098)\end{array}$ & $\begin{array}{l}0.46407 * * * \\
(0.106)\end{array}$ & $\begin{array}{l}-0.01685 \\
(0.091)\end{array}$ & $\begin{array}{l}0.46427 * * * \\
(0.100)\end{array}$ \\
\hline$L G D P C$ & $\begin{array}{l}0.01922 * * * \\
(0.007)\end{array}$ & $\begin{array}{l}-0.02060 * * * \\
(0.007)\end{array}$ & $\begin{array}{l}0.01624 * * \\
(0.006)\end{array}$ & $\begin{array}{l}-0.01854 * * * \\
(0.007)\end{array}$ \\
\hline Observations & 1,032 & 1,028 & 1,036 & 1,032 \\
\hline Number of banks & 133 & 133 & 132 & 132 \\
\hline $\operatorname{AR}(2)$ test: $p$-Val & 0.338 & 0.772 & 0.312 & 0.513 \\
\hline Hansen-J test $: p$-Val & 0.069 & 0.138 & 0.139 & 0.170 \\
\hline
\end{tabular}

Notes: $* * *$ indicates significance at the $1 \%$ level, while $* *$ and $*$ indicate significance at the $5 \%$ and $10 \%$ levels, respectively. 
Table 4. Abnormal loan growth, credit reporting system, and systemic risk in banking (SRISK)

\begin{tabular}{|c|c|c|c|c|c|c|}
\hline \multirow[b]{3}{*}{ Explanatory variables } & \multicolumn{6}{|c|}{ Dependent variables } \\
\hline & \multicolumn{6}{|c|}{ SRISK } \\
\hline & $\begin{array}{l}A L G= \\
A D L O A N\end{array}$ & $\begin{array}{l}A L G= \\
A L O A N G\end{array}$ & $\begin{array}{l}A L G= \\
A D L O A N\end{array}$ & $\begin{array}{l}A L G= \\
A L O A N G\end{array}$ & $\begin{array}{l}A L G= \\
A D L O A N\end{array}$ & $\begin{array}{l}A L G= \\
A L O A N G\end{array}$ \\
\hline Dependent var. $(-1)$ & $\begin{array}{l}0.55943 * * * \\
(0.072)\end{array}$ & $\begin{array}{l}0.57736^{* * * *} \\
(0.073)\end{array}$ & $\begin{array}{l}0.36216^{* * *} \\
(0.057)\end{array}$ & $\begin{array}{l}0.34445^{* * * *} \\
(0.054)\end{array}$ & $\begin{array}{l}0.57239 * * * \\
(0.070)\end{array}$ & $\begin{array}{l}0.57860 * * * \\
(0.069)\end{array}$ \\
\hline$A L G(-1)$ & $\begin{array}{l}0.31600 * * * \\
(0.110)\end{array}$ & $\begin{array}{l}0.06202 \\
(0.059)\end{array}$ & $\begin{array}{l}0.13511^{* * * *} \\
(0.043)\end{array}$ & $\begin{array}{l}0.06157 * * * \\
(0.023)\end{array}$ & $\begin{array}{l}0.01641 \\
(0.044)\end{array}$ & $\begin{array}{l}0.02877 \\
(0.025)\end{array}$ \\
\hline$A L G(-1) \times C R I N D E X(-1)$ & $\begin{array}{l}-0.06428^{* * *} \\
(0.02454)\end{array}$ & $\begin{array}{l}-0.33200 \\
(0.01497)\end{array}$ & & & & \\
\hline$A L G(-1) \times P R I V B U R(-1)$ & & & $\begin{array}{l}-0.41000 * * * \\
(0.144)\end{array}$ & $\begin{array}{l}-0.13098 * * \\
(0.090)\end{array}$ & & \\
\hline$A L G(-1) \times P U B R E G(-1)$ & & & & & $\begin{array}{l}0.52334 \\
(0.326)\end{array}$ & $\begin{array}{l}0.40341 \\
(0.178)\end{array}$ \\
\hline CRINDEX(-1) & $\begin{array}{l}0.28533 \\
(0.572)\end{array}$ & $\begin{array}{l}0.70723 \\
(0.579)\end{array}$ & & & & \\
\hline $\operatorname{PRIVBUR}(-1)$ & & & $\begin{array}{l}0.11553 * * \\
(0.049)\end{array}$ & $\begin{array}{l}0.15045^{* * *} \\
(0.047)\end{array}$ & & \\
\hline PUBREG(-1) & & & & & $\begin{array}{l}0.02055 \\
(0.068)\end{array}$ & $\begin{array}{l}-0.04098 \\
(0.051)\end{array}$ \\
\hline$E Q T A$ & $\begin{array}{l}-0.00057 \\
(0.001)\end{array}$ & $\begin{array}{l}-0.00113 \\
(0.001)\end{array}$ & $\begin{array}{l}-0.00158 \\
(0.002)\end{array}$ & $\begin{array}{l}-0.00186 \\
(0.002)\end{array}$ & $\begin{array}{l}-0.00112 \\
(0.001)\end{array}$ & $\begin{array}{l}-0.00134 \\
(0.001)\end{array}$ \\
\hline$L I Q$ & $\begin{array}{l}-0.02367 \\
(0.033)\end{array}$ & $\begin{array}{l}-0.05388 \\
(0.040)\end{array}$ & $\begin{array}{l}-0.05906^{*} \\
(0.031)\end{array}$ & $\begin{array}{l}-0.06454 * * \\
(0.026)\end{array}$ & $\begin{array}{l}-0.03936 \\
(0.031)\end{array}$ & $\begin{array}{l}-0.07056^{*} \\
(0.042)\end{array}$ \\
\hline$L L P$ & $\begin{array}{l}-0.72622 \\
(0.505)\end{array}$ & $\begin{array}{l}-0.90012 * \\
(0.496)\end{array}$ & $\begin{array}{l}-0.62084 \\
(0.429)\end{array}$ & $\begin{array}{l}-0.86689 * \\
(0.472)\end{array}$ & $\begin{array}{l}-0.75062 \\
(0.473)\end{array}$ & $\begin{array}{l}-0.82490 * \\
(0.436)\end{array}$ \\
\hline SIZE & $\begin{array}{l}0.02258 * * * \\
(0.004)\end{array}$ & $\begin{array}{l}0.02115^{* * *} \\
(0.004)\end{array}$ & $\begin{array}{l}0.02950 * * * \\
(0.005)\end{array}$ & $\begin{array}{l}0.02910 * * * \\
(0.006)\end{array}$ & $\begin{array}{l}0.02139 * * * \\
(0.004)\end{array}$ & $\begin{array}{l}0.02050^{* * * *} \\
(0.004)\end{array}$ \\
\hline TOBIN & $\begin{array}{l}-0.12923 * * \\
(0.060)\end{array}$ & $\begin{array}{l}-0.11095^{*} \\
(0.065)\end{array}$ & $\begin{array}{l}-0.14082 * * * \\
(0.051)\end{array}$ & $\begin{array}{l}-0.13611^{* *} \\
(0.056)\end{array}$ & $\begin{array}{l}-0.12479 * \\
(0.067)\end{array}$ & $\begin{array}{l}-0.10212 \\
(0.067)\end{array}$ \\
\hline ECOFREE & $\begin{array}{l}-0.05491 \\
(0.082)\end{array}$ & $\begin{array}{l}0.02971 \\
(0.073)\end{array}$ & $\begin{array}{l}-0.21251^{* *} \\
(0.099)\end{array}$ & $\begin{array}{l}-0.13315 \\
(0.095)\end{array}$ & $\begin{array}{l}-0.01518 \\
(0.097)\end{array}$ & $\begin{array}{l}-0.00396 \\
(0.095)\end{array}$ \\
\hline$L G D P C$ & $\begin{array}{l}0.01575^{* *} \\
(0.007)\end{array}$ & $\begin{array}{l}0.00741 \\
(0.007)\end{array}$ & $\begin{array}{l}0.00636 \\
(0.011)\end{array}$ & $\begin{array}{l}-0.00136 \\
(0.010)\end{array}$ & $\begin{array}{l}0.01474^{* *} \\
(0.006)\end{array}$ & $\begin{array}{l}0.01279 * * \\
(0.006)\end{array}$ \\
\hline Observations & 1,145 & 1,147 & 1,145 & 1,147 & 1,145 & 1,147 \\
\hline Number of banks & 136 & 135 & 136 & 135 & 136 & 135 \\
\hline $\mathrm{AR}(2)$ test: $p$-Val & 0.108 & 0.175 & 0.297 & 0.559 & 0.136 & 0.160 \\
\hline Hansen-J test : $p$-Val & 0.051 & 0.057 & 0.572 & 0.054 & 0.030 & 0.046 \\
\hline
\end{tabular}

Notes: $* * *$ indicates significance at the $1 \%$ level, while $* *$ and $*$ indicate significance at the $5 \%$ and $10 \%$ levels, respectively. 
Table 5. Abnormal loan growth, credit reporting system, and systemic risk in banking $(R C O R R)$

\begin{tabular}{|c|c|c|c|c|c|c|}
\hline \multirow[b]{2}{*}{ Explanatory variables } & \multicolumn{6}{|c|}{ RCORR } \\
\hline & $\begin{array}{l}A L G= \\
A D L O A N\end{array}$ & $\begin{array}{l}A L G= \\
A L O A N G\end{array}$ & $\begin{array}{l}A L G= \\
A D L O A N\end{array}$ & $\begin{array}{l}A L G= \\
A L O A N G\end{array}$ & $\begin{array}{l}A L G= \\
A D L O A N\end{array}$ & $\begin{array}{l}A L G= \\
A L O A N G\end{array}$ \\
\hline Dependent var. (-1) & $\begin{array}{l}0.40775^{* * * *} \\
(0.066)\end{array}$ & $\begin{array}{l}0.61763^{* * * *} \\
(0.057)\end{array}$ & $\begin{array}{l}0.58730 * * * \\
(0.062)\end{array}$ & $\begin{array}{l}0.44272 * * * \\
(0.055)\end{array}$ & $\begin{array}{l}0.60112^{* * * *} \\
(0.067)\end{array}$ & $\begin{array}{l}0.60243^{* * * *} \\
(0.064)\end{array}$ \\
\hline$A L G(-1)$ & $\begin{array}{l}0.41273 * * * \\
(0.112)\end{array}$ & $\begin{array}{l}0.06935 \\
(0.063)\end{array}$ & $\begin{array}{l}0.22021 * * * \\
(0.056)\end{array}$ & $\begin{array}{l}0.04117 \\
(0.028)\end{array}$ & $\begin{array}{l}0.12370^{* * * *} \\
(0.039)\end{array}$ & $\begin{array}{l}0.05419 * * \\
(0.022)\end{array}$ \\
\hline$A L G(-1) \times C R I N D E X(-1)$ & $\begin{array}{l}-0.0735 * * * \\
(0.02467)\end{array}$ & $\begin{array}{l}-0.00296 \\
(0.01544)\end{array}$ & & & & \\
\hline$A L G(-1) \times P R I V B U R(-1)$ & & & $\begin{array}{l}-0.32954 * * \\
(0.147)\end{array}$ & $\begin{array}{l}-0.06171^{*} \\
(0.070)\end{array}$ & & \\
\hline$A L G(-1) \times P U B R E G(-1)$ & & & & & $\begin{array}{l}-0.06526 \\
(0.323)\end{array}$ & $\begin{array}{l}0.08540 \\
(0.215)\end{array}$ \\
\hline CRINDEX(-1) & $\begin{array}{l}1.46466^{* *} \\
(0.691)\end{array}$ & $\begin{array}{l}1.61701^{* * * *} \\
(0.611)\end{array}$ & & & & \\
\hline $\operatorname{PRIVBUR}(-1)$ & & & $\begin{array}{l}0.13335^{* * *} \\
(0.037)\end{array}$ & $\begin{array}{l}0.18894 * * * \\
(0.044)\end{array}$ & & \\
\hline PUBREG(-1) & & & & & $\begin{array}{l}-0.1748^{* * * *} \\
(0.066)\end{array}$ & $\begin{array}{l}-0.1672 * * * \\
(0.061)\end{array}$ \\
\hline$E Q T A$ & $\begin{array}{l}0.00309^{*} \\
(0.002)\end{array}$ & $\begin{array}{l}0.00085 \\
(0.001)\end{array}$ & $\begin{array}{l}0.00216 \\
(0.001)\end{array}$ & $\begin{array}{l}0.00305 \\
(0.002)\end{array}$ & $\begin{array}{l}0.00155 \\
(0.001)\end{array}$ & $\begin{array}{l}0.00119 \\
(0.001)\end{array}$ \\
\hline$L I Q$ & $\begin{array}{l}-0.1059^{* * *} \\
(0.040)\end{array}$ & $\begin{array}{l}-0.11239 * * \\
(0.044)\end{array}$ & $\begin{array}{l}-0.04062 \\
(0.028)\end{array}$ & $\begin{array}{l}-0.1219 * * * \\
(0.046)\end{array}$ & $\begin{array}{l}-0.06459 * * \\
(0.033)\end{array}$ & $\begin{array}{l}-0.1174 * * * \\
(0.041)\end{array}$ \\
\hline$L L P$ & $\begin{array}{l}-0.46588 \\
(0.577)\end{array}$ & $\begin{array}{l}-0.50037 \\
(0.523)\end{array}$ & $\begin{array}{l}-0.41063 \\
(0.371)\end{array}$ & $\begin{array}{l}-0.77823^{*} \\
(0.443)\end{array}$ & $\begin{array}{l}-0.22061 \\
(0.403)\end{array}$ & $\begin{array}{l}-0.27085 \\
(0.421)\end{array}$ \\
\hline SIZE & $\begin{array}{l}0.05123^{* * *} \\
(0.008)\end{array}$ & $\begin{array}{l}0.03223^{* * * *} \\
(0.005)\end{array}$ & $\begin{array}{l}0.03630 \text { *** } \\
(0.005)\end{array}$ & $\begin{array}{l}0.05103 * * * \\
(0.007)\end{array}$ & $\begin{array}{l}0.03325^{* * *} \\
(0.005)\end{array}$ & $\begin{array}{l}0.03263^{* * * *} \\
(0.005)\end{array}$ \\
\hline TOBIN & $\begin{array}{l}-0.2599 * * * \\
(0.074)\end{array}$ & $\begin{array}{l}-0.11379 \\
(0.069)\end{array}$ & $\begin{array}{l}-0.12352^{* *} \\
(0.056)\end{array}$ & $\begin{array}{l}-0.12364 * \\
(0.068)\end{array}$ & $\begin{array}{l}-0.10567 \\
(0.069)\end{array}$ & $\begin{array}{l}-0.06615 \\
(0.072)\end{array}$ \\
\hline ECOFREE & $\begin{array}{l}0.75880 * * * \\
(0.113)\end{array}$ & $\begin{array}{l}0.51496^{* * * *} \\
(0.097)\end{array}$ & $\begin{array}{l}0.28627^{* * * *} \\
(0.082)\end{array}$ & $\begin{array}{l}0.60510 * * * \\
(0.107)\end{array}$ & $\begin{array}{l}0.33841^{* * *} \\
(0.095)\end{array}$ & $\begin{array}{l}0.35444 * * * \\
(0.094)\end{array}$ \\
\hline$L G D P C$ & $\begin{array}{l}-0.0551^{* * *} \\
(0.012)\end{array}$ & $\begin{array}{l}-0.0373 * * * \\
(0.009)\end{array}$ & $\begin{array}{l}-0.0418^{* * *} \\
(0.010)\end{array}$ & $\begin{array}{l}-0.0716^{* * *} \\
(0.013)\end{array}$ & $\begin{array}{l}-0.0193 * * * \\
(0.007)\end{array}$ & $\begin{array}{l}-0.0191 * * * \\
(0.007)\end{array}$ \\
\hline Observations & 1,140 & 1,142 & 1,140 & 1,142 & 1,140 & 1,142 \\
\hline Number of banks & 136 & 135 & 136 & 135 & 136 & 135 \\
\hline $\mathrm{AR}(2)$ test: $p$-Val & 0.299 & 0.585 & 0.708 & 0.805 & 0.801 & 0.657 \\
\hline Hansen-J test : $p$-Val & 0.109 & 0.063 & 0.137 & 0.382 & 0.097 & 0.139 \\
\hline
\end{tabular}

Notes: $* * *$ indicates significance at the $1 \%$ level, while $* *$ and $*$ indicate significance at the $5 \%$ and $10 \%$ levels, respectively. 